\title{
Translating IL-6 biology into effective treatments
}

\section{Ernest H. Choy (D, Fabrizio De Benedetti, Tsutomu Takeuchi®D, Misato Hashizume, Markus R. John and Tadamitsu Kishimoto}

Abstract | In 1973, IL-6 was identified as a soluble factor that is secreted by T cells and is important for antibody production by B cells. Since its discovery more than 40 years ago, the IL-6 pathway has emerged as a pivotal pathway involved in immune regulation in health and dysregulation in many diseases. Targeting of the IL-6 pathway has led to innovative therapeutic approaches for various rheumatic diseases, such as rheumatoid arthritis, juvenile idiopathic arthritis, adult-onset Still's disease, giant cell arteritis and Takayasu arteritis, as well as other conditions such as Castleman disease and cytokine release syndrome. Targeting this pathway has also identified avenues for potential expansion into several other indications, such as uveitis, neuromyelitis optica and, most recently, COVID-19 pneumonia. To mark the tenth anniversary of anti-IL-6 receptor therapy worldwide, we discuss the history of research into IL- 6 biology and the development of therapies that target IL-6 signalling, including the successes and challenges and with an emphasis on rheumatic diseases.

Cytokine inhibitors have transformed the outcome of many chronic inflammatory diseases. A decade has passed since the approval of anti-IL-6 receptor (anti-IL-6R) therapy, which is now used worldwide in various rheumatic diseases, such as rheumatoid arthritis (RA), juvenile idiopathic arthritis (JIA), adult-onset Still's disease (AOSD), giant cell arteritis (GCA) and Takayasu arteritis, as well as other conditions such as Castleman disease and cytokine release syndrome (CRS). To mark this anniversary, we discuss the 40-year history of translational research into IL-6 biology and the subsequent development of therapies targeting this pivotal cytokine pathway, which helps to inform future biological and clinical research.

\section{From signalling to drug discovery}

The journey from the discovery of IL- 6 biology to the development of an IL-6 pathway inhibitor as a potential treatment for various diseases started coincidentally with the meeting of two research groups in Japan. In 1973, researchers at Osaka University led by Tadamitsu Kishimoto first reported that a soluble factor secreted by $\mathrm{T}$ cells was important for antibody production by B cells (FIG. 1); subsequently, this soluble factor was cloned as IL-6, which turned out to have various roles in several autoimmune diseases ${ }^{1,2}$. At the same time, researchers at Chugai Pharmaceutical were exploring new avenues for drug development for autoimmune diseases. In the late 1980s, the two groups started to collaborate to further advance the understanding of the biological role of IL- 6 in various autoimmune diseases and the development of IL-6 inhibitors as treatment options. To increase their collaborative potential, the two research groups even moved to adjoining laboratories at Osaka University. The university researchers led efforts to identify IL-6 signalling mechanisms and the biological effects of IL-6, whereas the company focused on developing and characterizing IL-6 inhibitors as potential new treatments for autoimmune diseases ${ }^{3-5}$.

The traditional approach of searching for small-molecule inhibitors proved challenging when the research team found that IL-6 signal transduction occurred through a hexameric high-affinity complex of IL-6, IL-6R and glycoprotein 130 (gp130) (FIG. 2a). Moreover, both soluble IL-6R (sIL-6R) and membrane-bound IL-6R (mIL-6R) can be part of the hexameric complex; hence, the binding region of IL-6-IL-6R-gp130 was considered too complex and broad for a small-molecule compound to inhibit the IL- 6 signal pathway $^{6,7}$. The aforementioned mIL-6R and sIL-6R forms are associated with so-called classical signalling and trans-signalling pathways, respectively, the details of which and corresponding avenues for drug development have been reviewed extensively elsewhere ${ }^{4}$. Both signalling routes involve phosphorylation of Janus kinase 1 (JAK1), JAK2 and tyrosine kinase 2 (TYK2), which can also be targeted therapeutically with different molecules but are not the focus of this article ${ }^{4}$. The decision to target IL-6R rather than IL-6 itself was made, taking into consideration that concentrations of the receptor have less interpatient variability than concentrations of IL-6, potentially simplifying dose and regimen selection ${ }^{8,9}$. With concurrent advances in biotechnology, the two groups decided to develop a humanized monoclonal antibody targeting IL-6 $\mathrm{R}^{10-12}$. The resulting humanized antibody to IL-6R, tocilizumab, binds to mIL-6R and sIL-6R and inhibits IL-6 signalling by preventing IL- 6 from binding to IL-6 $\mathrm{R}^{11,12}$. The therapeutic benefit of this antibody to IL-6R led to the development of several antibodies to IL-6 (sirukumab, olokizumab and clazakizumab).

\section{Initial therapeutic applications}

As IL-6 is well known to have various physiological roles, in considering IL-6 as a therapeutic target, its homeostatic role versus its pathogenic role in various autoimmune diseases was extensively debated ${ }^{3,4}$. However, utilizing cell-based assays, animal models and ex vivo serum and tissue analyses, scientists identified several candidate diseases that might benefit from the use of IL-6 inhibition (TABLE 1).

A 1988 publication reported that IL-6 is an important growth factor in myeloma cells ${ }^{13}$. Oncologists in France conducted an open-label clinical trial of a mouse anti-IL-6 in patients with multiple myeloma, the second most common type of blood cancer 


\section{PERSPECTIVES}

after leukaemia ${ }^{14}$. Although none of the patients treated had an improved outcome or achieved remission in the initial report of the trial, post-hoc analysis revealed that treatment with the anti-IL- 6 showed some efficacy in those patients who produced low concentrations of IL-6 (REF. $\left.{ }^{15}\right)$. More than 20 years later, a clinical trial evaluated whether the addition of a different chimeric monoclonal antibody to IL-6, siltuximab, to the bortezomib-melphalan-prednisone regimen would be beneficial to patients with newly diagnosed multiple myeloma; however, this IL-6 inhibitor also failed to improve outcomes ${ }^{16}$.

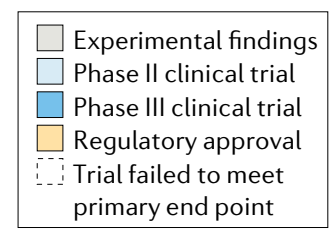

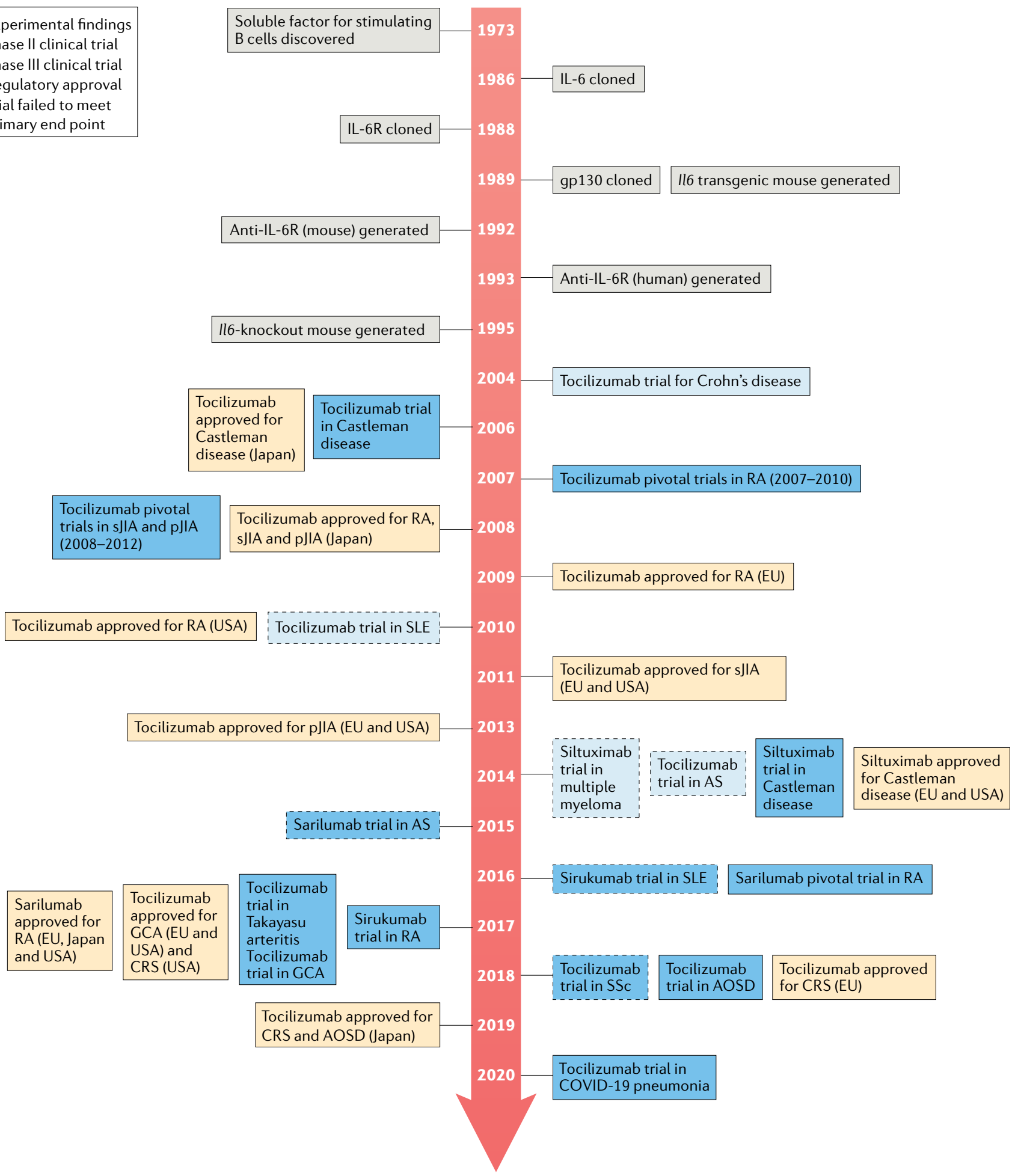

Tocilizumab approved for RA, 2008

Fig. 1 | Timeline of the discovery of IL-6 and IL-6-targeted therapies. The timeline shows progress in the field of IL-6 pathway inhibition following the initial identification of a B cell stimulation factor in 1973, and the more definitive biochemical and molecular studies carried out in the 1980s and 1990s, to clinical trials and approvals in various diseases in the 2000s and up to the present day. AOSD, adult-onset Still's disease; AS, ankylosing spondylitis; CRS, cytokine release syndrome; GCA, giant cell arteritis; gp130, glycoprotein 130; IL-6R, IL-6 receptor; pJIA, polyarticular course juvenile idiopathic arthritis; RA, rheumatoid arthritis; sJIA, systemic juvenile idiopathic arthritis; SLE, systemic lupus erythematosus; SSc, systemic sclerosis. 
In 1989, a publication described constitutive overproduction of IL-6 from the germinal centres of hyperplastic lymph nodes in patients with Castleman disease, a lymphoproliferative disorder, and a correlation of serum IL-6 concentrations with clinical abnormalities ${ }^{17}$. Consistent with these observations, transgenic mice carrying the human Il6 gene, under the control of an immunoglobulin promoter, developed clinical features of Castleman disease including splenomegaly, lymph node enlargement and high concentrations of IL-6 and $\operatorname{IgG}^{18,19}$. In a 1994 case report, administration of a mouse neutralizing antibody to IL-6 to a patient with Castleman disease seemed to be therapeutically effective $^{20}$. Tocilizumab also had positive effects in a small case series of seven patients in 2000 and in a multicentre, prospective, open-label study in 2005 that included 28 patients with Castleman disease $\mathrm{e}^{21,22}$. In the prospective study, bi-weekly treatment with tocilizumab consistently alleviated lymphadenopathy and improved all inflammatory parameters over 60 weeks ${ }^{22}$. A double-blind, placebo-controlled trial of siltuximab also showed efficacy in this indication $^{23}$. Subsequently, tocilizumab was approved for the treatment of Castleman disease in Japan and siltuximab was approved for this indication in various countries.

A 1995 study reported that serum concentrations of IL- 6 and sIL-6R were elevated in patients with Crohn's disease, a type of inflammatory bowel disease, and correlated with C-reactive protein levels ${ }^{24}$. On the basis of these observations, tocilizumab was evaluated in a placebo-controlled phase II randomized controlled trial (RCT) with patients with active Crohn's disease (defined as a Crohn's Disease Activity Index score of $\geq 150\left(\right.$ REF. $\left.^{25}\right)$ ). The primary end point, a reduction of the Crohn's Disease Activity Index score of $\geq 70$ points, was met by $80 \%$ of the patients who received bi-weekly tocilizumab, compared with $31 \%$ of the placebo-treated patients, demonstrating the substantial efficacy of tocilizumab. However, the development of tocilizumab for Crohn's disease did not proceed owing to rare reports of gastrointestinal perforations observed in concurrent clinical trials in arthritis and because of an increased understanding of the homeostatic role of IL- 6 in the intestinal epithelium ${ }^{26}$. Together, these findings suggested that patients with Crohn's disease might be at increased risk of potential detrimental effects of IL-6 inhibition.

\section{IL-6 inhibition in RA}

The development path for an IL-6 inhibitor for the treatment of RA, the most common chronic autoimmune disorder that primarily affects joints, began in the early 1990s, when cell-based experiments revealed that IL-6 might be involved in osteoporosis, cartilage destruction and synovial inflammation associated with $\mathrm{RA}^{27-30}$. In mouse models of collagen-induced and antigen-induced arthritis, IL- 6 inhibition prevented the development of arthritis but did not ameliorate arthritis once the disease was established ${ }^{31-33}$. In a 1993 study, the administration of a mouse monoclonal antibody to IL-6 to patients with RA resulted in improvements of disease symptoms and laboratory measures of disease activity, although the effects were transient ${ }^{34}$. In 2000, the efficacy and tolerability of tocilizumab was investigated in a case series of 11 patients with refractory RA; the treatment was well tolerated and led to both clinical and biochemical improvements ${ }^{35}$. On the basis of these results, larger and confirmatory double-blind RCTs of tocilizumab were conducted in patients with refractory RA $^{36-40}$. Tocilizumab improved clinical signs and symptoms of RA, laboratory parameters and radiological manifestations and also ameliorated the effects of RA on patient-reported outcomes, activities of daily living and quality of life, when administered as monotherapy or in combination with conventional synthetic DMARDs (csDMARDs) ${ }^{41-45}$. These and other studies led to tocilizumab receiving marketing authorization (FIG. 1) for patients with early RA who were not previously treated with methotrexate and those with established RA and an inadequate response to previous treatment with DMARDs or TNF antagonists; in these patients, tocilizumab is administered in combination with methotrexate or as monotherapy if methotrexate is not tolerated or continued treatment with methotrexate is not appropriate.

A notable finding of further clinical investigation in several RCTs and real-world data was that, unlike TNF inhibitors, tocilizumab monotherapy was superior to methotrexate or other csDMARDs for reducing the signs, symptoms and radiographic progression of $\mathrm{RA}^{39,40,46-59}$. In particular, a head-to-head, double-blind, double-dummy RCT found that, when used as monotherapy, tocilizumab was superior to the TNF inhibitor adalimumab in measures of disease activity and several other outcomes ${ }^{46}$. On the basis of these results, EULAR recommendations for the management of RA named IL-6 pathway inhibitors as one of the preferred treatment options for patients for whom methotrexate is inappropriate ${ }^{60}$. Interestingly, the clinical benefits of IL- 6 inhibition might be attributable, in part, to the beneficial effects of IL-6 inhibition on bone and cartilage turnover, which are supported by data from prospective cohort studies showing that tocilizumab monotherapy achieves better repair of focal bone erosions than TNF inhibition in patients with $\mathrm{RA}^{60-70}$. Besides promoting joint inflammation and damage through effects on chondrocytes, osteoclasts, macrophages and fibroblasts, IL- 6 mediates systemic inflammation in RA. IL- 6 affects $\mathrm{T}$ cell and $\mathrm{B}$ cell differentiation and is the key driver of the acute-phase response in RA. Key symptoms and comorbidities such as pain, fatigue, anxiety, depression, anaemia and cardiovascular disease can be mediated by IL-6 (REFS ${ }^{71,72}$ ), as shown in FIG. 2c.

Since tocilizumab was approved for RA, sarilumab, an alternative monoclonal antibody to IL-6R, has also demonstrated efficacy and safety and has been approved for the treatment of $\mathrm{RA}^{73-75}$. Three other monoclonal antibodies to IL-6, sirukumab, olokizumab and clazakizumab, have also been tested in clinical trials in RA. In phase III RCTs that included patients with RA refractory to treatment with csDMARDs and biologic DMARDs, sirukumab was superior to placebo in improving disease activity, physical function and health-related quality of life, as well as inhibiting radiographic disease progression $^{76,77}$. However, monotherapy with sirukumab was similar but not superior to adalimumab and efforts to obtain regulatory approval in RA were terminated ${ }^{78}$. Phase II trials of olokizumab demonstrated therapeutic benefit, and phase III trials are ongoing ${ }^{79}$. However, the development of clazakizumab as a treatment for RA has also been terminated.

\section{IL-6 inhibition in JIA and AOSD}

JIA is a term encompassing all forms of chronic arthritis affecting children younger than 16 years of age ${ }^{80}$. JIA exists as several different subtypes: oligoarticular JIA, polyarticular JIA, juvenile psoriatic arthritis (PsA), enthesitis-related arthritis and systemic JIA (sJIA). In sJIA, arthritis is associated with prominent systemic features, including high spiking fever, rash, serositis and inflammatory signs. This disease is further characterized by high morbidity and mortality rates, joint destruction, functional disability and growth retardation $^{80}$. Concentrations of IL-6 are markedly elevated in the serum and synovial fluid of patients with sJIA, and a vast body 


\section{PER SPECTIVES}

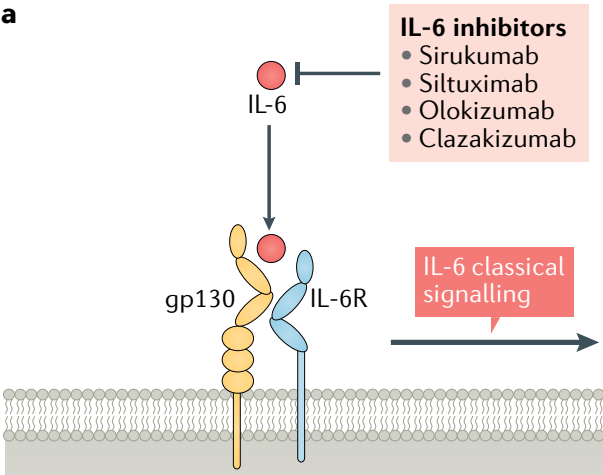

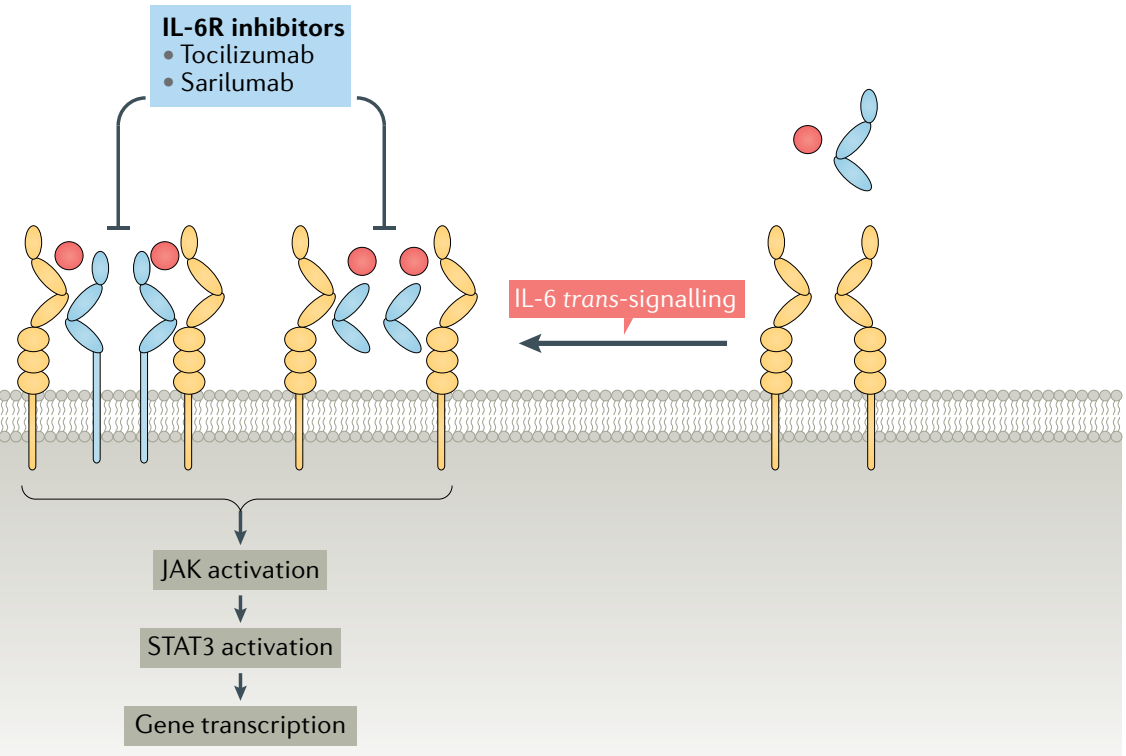

IL-6R inhibitors

Tocilizumab

b

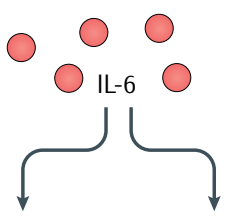

Local inflammation

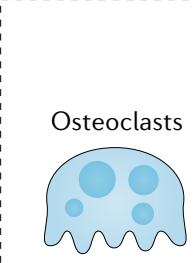

Osteoclast

differentiation

and activation

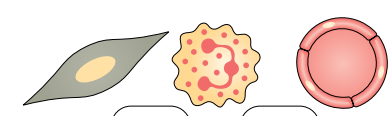

$$
\begin{gathered}
\text { Chemokines RANKL } \\
\text { Cytokines }
\end{gathered}
$$

Dysregulated production of mediators of inflammation,

bone homeostasis, cell

proliferation and matrix and bone degradation
Systemic inflammation

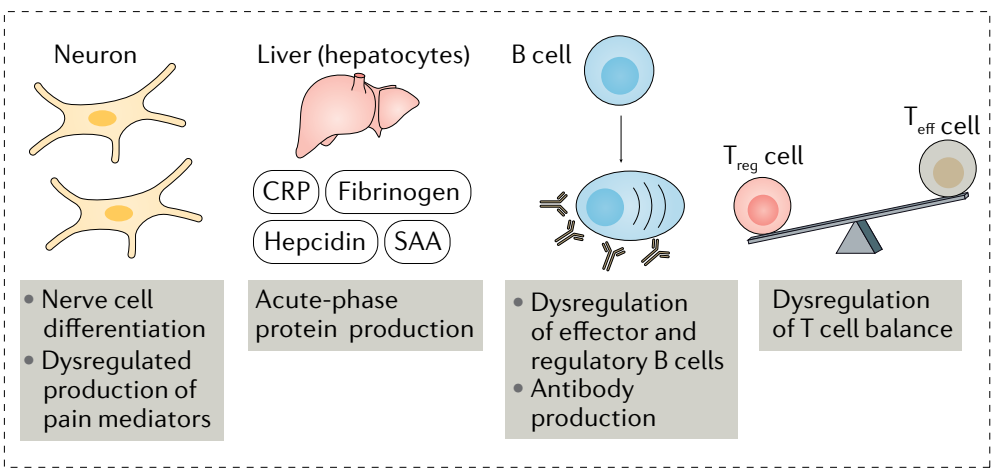

C
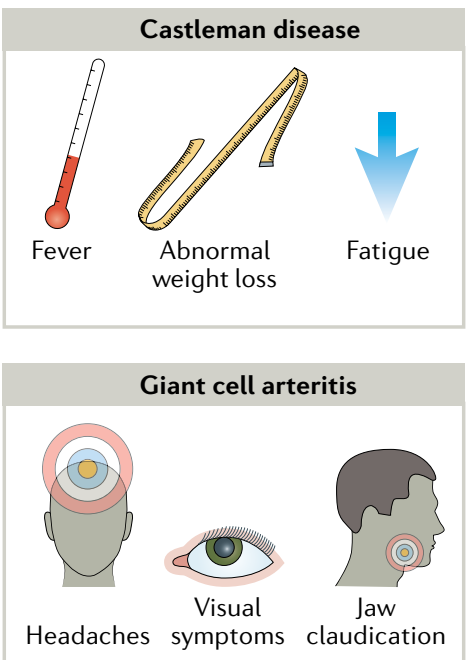
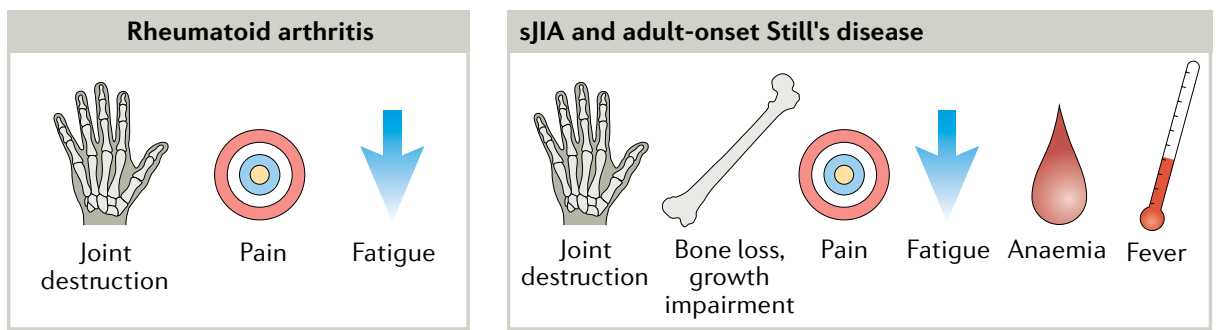

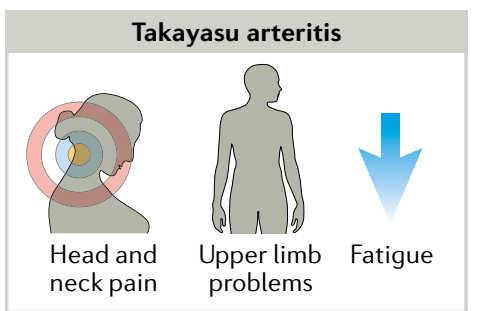


4 Fig. 2 | Cell signalling pathways and the physiological role of IL-6 in diseases. IL-6 participates in a broad spectrum of biological events, such as synovial inflammation, immune responses, haematopoiesis and acute-phase reactions. a | IL-6 binds to IL-6 receptor (IL-6R) and glycoprotein 130 (gp130) to form a hexameric complex. Both membrane-bound IL-6R and soluble IL-6R can be part of the hexameric complex and are associated with the classical signalling and trans-signalling pathways, respectively. Intracellular signalling pathways involve the Janus kinase (JAK) and signal transducer and activator of transcription (STAT) pathway. Pharmacological inhibitors of IL-6 signalling prevent IL-6 from binding to IL-6R by targeting either the cytokine itself or the receptor. $\mathbf{b} \mid$ In the context of disease, IL-6 can have both local inflammatory and systemic effects. Some of the manifestations of the diseases for which IL-6 inhibitors are approved could be explained by the effects of IL-6, on the basis of both preclinical and clinical data. IL-6 has been implicated in the pathogenesis of diseases, including rheumatoid arthritis, systemic juvenile idiopathic arthritis (s)IA), Castleman disease, giant cell arteritis, Takayasu arteritis and cytokine release syndrome, among others. c $\mid$ As IL-6 has multiple roles in the dysfunction of the immune and inflammatory systems, anti-IL-6R therapy could relieve various symptoms such as fever, fatigue, pain, joint destruction, anaemia and others. CRP, C-reactive protein; MMP, matrix metalloprotease; RANKL, receptor activator of NF- $\kappa B$ ligand; SAA, serum amyloid $A ; T_{\text {eff }}$ cell, effector $T$ cell; $T_{\text {reg }}$ cell, regulatory $T$ cell; $V E G F$, vascular endothelial growth factor.

of evidence from cell-based experiments and animal models demonstrates that IL-6 overproduction seems to explain most, if not all, of the clinical and laboratory features of the disease including fever spikes, acute-phase response, anaemia, growth retardation and systemic osteoporosis ${ }^{81-85}$. In 2005, clinical trials of tocilizumab in patients with sJIA conducted in the UK and Japan provided proof of principle of the efficacy of IL-6 inhibition in this severe paediatric condition ${ }^{86,87}$. Two subsequent trials of tocilizumab in $>150$ children with sJIA confirmed extensive improvements in the signs and symptoms of disease following treatment with tocilizumab and demonstrated the clinically relevant glucocorticoid-sparing potential of IL-6 inhibition $^{88-92}$. The efficacy and safety of IL-6 inhibition in sJIA have also been confirmed in real-world studies ${ }^{93}$. Reversal of sJIA-associated growth retardation has also been demonstrated with IL-6 inhibition, with patients experiencing catch-up growth during treatment with tocilizumab ${ }^{92}$.

AOSD and sJIA are increasingly considered to be the same disease, with AOSD occurring in adulthood and SJIA in childhood. In a double-blind RCT of 27 patients with AOSD refractory to treatment with glucocorticoids, an ACR50 response (reflecting 50\% improvement) at week 4 was achieved in $\sim 61 \%$ of patients treated with tocilizumab, compared with $\sim 31 \%$ of placebo-treated patients, although the difference was not statistically significant $t^{94}$. Patients in the tocilizumab group also had improvements in systemic symptoms and a decreased dose of glucocorticoids compared with the placebo group. On the basis of data from this trial, tocilizumab was approved for the treatment of AOSD in Japan in 2019.

Polyarticular JIA is characterized by a potentially destructive disease course.
Trials of tocilizumab were undertaken in polyarticular JIA from 2009 on the basis of results obtained in RA. In a small trial in 19 patients, $100 \%$ of patients met the criteria for a good response after 48 weeks of treatment with tocilizumab ${ }^{95}$. In a pivotal phase III trial and its subsequent long-term extension study in 188 patients, inhibition of IL-6 led to sustained and clinically meaningful improvements after 2 years, and skeletal growth was also improved by treatment with tocilizumab ${ }^{96,97}$. Another antibody to IL-6R, sarilumab, is in phase II trials for polyarticular JIA ${ }^{98}$ and sJIA ${ }^{99}$.

\section{IL-6 inhibition in SpA}

Seronegative spondyloarthritis (SpA) is a group of inflammatory rheumatic diseases, including ankylosing spondylitis (AS) and PsA, with common clinical and aetiological features, such as axial and peripheral inflammatory arthritis, enthesitis and extra-articular manifestations ${ }^{100}$. The absence of the serological markers rheumatoid factor and antibodies to cyclic citrullinated peptides differentiates SpA from RA. AS is a chronic, debilitating and gradually progressive inflammatory rheumatic disease that primarily affects the axial skeleton and sacroiliac joints, but can also affect the peripheral joints ${ }^{101}$. Serum IL- 6 concentrations are elevated in patients with AS and correlate with disease activity ${ }^{102}$. However, tocilizumab failed to show therapeutic benefit in AS in two double-blind RCTs in 2014 (REF. ${ }^{103}$ ). Sarilumab was also ineffective as a treatment for AS in a $2015 \mathrm{RCT}^{104}$. The conclusion from these RCTs is that IL-6 is not a therapeutic target in AS.

PsA is a chronic immune-mediated disease characterized by widespread musculoskeletal inflammation and is the major comorbidity associated with psoriasis ${ }^{105}$. The rationale for inhibiting
IL-6 in PsA was based on a small number of studies that demonstrated elevated concentrations of IL- 6 in both the serum and the synovial fluid of patients with PsA ${ }^{106,107}$. In a placebo-controlled phase II RCT, clazakizumab improved arthritis, enthesitis and dactylitis in patients with PsA, but with minimal improvements in skin disease ${ }^{108}$. Currently, development of clazakizumab for this indication seems to have been terminated.

\section{IL-6 inhibition in SLE and SSc}

In 1990, a study in NZB/W F1 mice, an animal model of systemic lupus erythematosus (SLE), suggested that IL-6 could have a role in the pathogenesis of immune complex-mediated glomerulonephritis ${ }^{109}$. Moreover, IL-6 concentrations are elevated in serum and urine samples from patients with SLE or lupus nephritis and correlate with disease activity ${ }^{110,111}$. In an open-label phase I study in 16 patients with SLE, treatment with tocilizumab improved disease activity; notably, arthritis improved in all seven patients who had arthritis at baseline and resolved in four of them ${ }^{112,113}$. Levels of antibodies to double-stranded DNA decreased even after adjustment for the decrease in total IgG titres following tocilizumab treatment ${ }^{112}$. These changes, together with a decrease in the frequency of circulating plasma cells, suggested a specific effect of IL-6 inhibition on autoantibody-producing B cells. However, further studies with sirukumab did not demonstrate a clinically meaningful benefit of IL-6 pathway inhibition in patients with lupus nephritis or SLE ${ }^{114,115}$. These conflicting results in SLE have tempered further clinical development. Whether IL-6 inhibition might be effective for some manifestations of SLE and not others requires further studies.

IL-6 is also implicated in the pathogenesis of systemic sclerosis (SSc). In the bleomycin-induced mouse model of SSc, IL-6 blockade reduced skin fibrosis, $\alpha$-smooth-muscle actin protein expression, hydroxyproline content and myofibroblast counts ${ }^{116}$. Dermal fibroblasts from patients with SSc constitutively express more IL-6 than those from healthy controls, and serum IL- 6 concentrations are elevated in patients with early SSc ${ }^{117,118}$. In a 2010 report, softening of skin sclerosis was observed in two patients with diffuse cutaneous SSc who received tocilizumab treatment ${ }^{119}$. In a double-blind phase II RCT in 87 patients with active diffuse SSc, fewer patients in the tocilizumab group had a decline in forced 
Table 1 | Evidence for the effects of IL-6 inhibition on diseases

\begin{tabular}{|c|c|c|c|c|c|}
\hline Disease & Cell-based assays & Animal models & Biomarkers & Clinical trials & $\begin{array}{l}\text { Drugs } \\
\text { indicated }\end{array}$ \\
\hline $\begin{array}{l}\text { Multiple } \\
\text { myeloma }\end{array}$ & $\begin{array}{l}\text { IL-6 promotes myeloma } \\
\text { cell proliferation }\end{array}$ & $\begin{array}{l}\text { In the KPMM2 xenograft } \\
\text { model, growth is IL-6 } \\
\text { dependent }^{176}\end{array}$ & $\begin{array}{l}\text { Serum concentrations } \\
\text { of IL-6 correlate with } \\
\text { disease severity in } \\
\text { plasma cell leukaemia }^{177}\end{array}$ & $\begin{array}{l}\text { No improvement in clinical } \\
\text { outcomes }^{14,16}\end{array}$ & None \\
\hline Crohn's disease & $\begin{array}{l}\text { IL-6 activates mucosal } \\
\text { Tcells }{ }^{178}\end{array}$ & $\begin{array}{l}\text { IL-6R blockade promotes } \\
\text { T cell apoptosis, which } \\
\text { contributes to chronic } \\
\text { intestinal inflammation in } \\
\text { the CD4 adoptive transfer } \\
\text { colitis model }^{178}\end{array}$ & $\begin{array}{l}\text { Serum concentrations } \\
\text { of sIL-6R are increased } \\
\text { in active disease }{ }^{24} \text {; } \\
\text { concentrations of IL-6 } \\
\text { and sIL-6R are increased } \\
\text { in colonic organ cultures } \\
\text { using specimens from } \\
\text { patients with active } \\
\text { disease }^{179}\end{array}$ & $\begin{array}{l}\text { Tocilizumab had a clinical } \\
\text { effect in a pilot study }{ }^{25}\end{array}$ & None \\
\hline $\begin{array}{l}\text { Castleman } \\
\text { disease }\end{array}$ & $\begin{array}{l}\mathrm{IL}-6 \text { is produced by } \\
\text { affected germinal } \\
\text { centres }^{17}\end{array}$ & $\begin{array}{l}\text { Il6 transgenic mice } \\
\text { develop clinical features } \\
\text { of Castleman disease }{ }^{19}\end{array}$ & $\begin{array}{l}\text { Increased serum } \\
\text { concentrations of IL-6 } \\
\text { in active disease }^{17}\end{array}$ & $\begin{array}{l}\text { Tocilizumab and siltuximab } \\
\text { showed efficacy in clinical } \\
\text { studies }^{22,23}\end{array}$ & $\begin{array}{l}\text { Tocilizumab, } \\
\text { siltuximab }\end{array}$ \\
\hline Systemic JIA & $\begin{array}{l}\text { Increased production of } \\
\text { IL- } 6 \text { by PBMCs }{ }^{180}\end{array}$ & $\begin{array}{l}\text { Il6 transgenic mice develop } \\
\text { a skeletal phenotype } \\
\text { resembling abnormalities } \\
\text { observed in children with } \\
\text { chronic inflammatory } \\
\text { diseases }^{84}\end{array}$ & $\begin{array}{l}\text { Serum concentrations } \\
\text { of IL- } 6 \text { are increased in } \\
\text { patients with JIA and } \\
\text { correlate with disease } \\
\text { activity }^{81,181}\end{array}$ & $\begin{array}{l}\text { Tocilizumab improved } \\
\text { disease activity and } \\
\text { reversed growth } \\
\text { retardation } \\
86-91,93,95,182\end{array}$ & Tocilizumab \\
\hline $\begin{array}{l}\text { Adult-onset } \\
\text { Still's disease }\end{array}$ & NA & NA & $\begin{array}{l}\text { Serum concentrations of } \\
\text { IL-6 are increased }{ }^{183}\end{array}$ & $\begin{array}{l}\text { Tocilizumab showed } \\
\text { some clinical benefit and } \\
\text { steroid-sparing effects }\end{array}$ & Tocilizumab \\
\hline $\begin{array}{l}\text { Ankylosing } \\
\text { spondylitis }\end{array}$ & NA & NA & $\begin{array}{l}\text { Serum concentrations } \\
\text { of IL- } 6 \text { are increased and } \\
\text { correlate with disease } \\
\text { activity }^{102}\end{array}$ & $\begin{array}{l}\text { Tocilizumab and sarilumab } \\
\text { failed to show therapeutic } \\
\text { benefit in randomized } \\
\text { controlled trials }^{103,104}\end{array}$ & None \\
\hline $\begin{array}{l}\text { Systemic } \\
\text { sclerosis }\end{array}$ & $\begin{array}{l}\text { Increased production of } \\
\text { IL- } 6 \text { by PBMCs }{ }^{185}\end{array}$ & $\begin{array}{l}\text { IL- } 6 \text { blockade improved } \\
\text { disease in the bleomycin } \\
\text { mouse model }{ }^{116}\end{array}$ & $\begin{array}{l}\text { Production of IL-6 } \\
\text { increased in dermal } \\
\text { fibroblasts and serum } \\
\text { concentrations of IL-6 } \\
\text { increased }^{117,118}\end{array}$ & $\begin{array}{l}\text { Tocilizumab had a } \\
\text { potentially clinically } \\
\text { important effect on the } \\
\text { preservation of lung } \\
\text { function }^{120,121}\end{array}$ & None \\
\hline $\begin{array}{l}\text { Giant cell } \\
\text { arteritis }\end{array}$ & NA & NA & $\begin{array}{l}\text { Serum concentrations of } \\
\text { IL- } 6 \text { increased in active } \\
\text { disease }^{124}\end{array}$ & $\begin{array}{l}\text { Tocilizumab was } \\
\text { superior to placebo } \\
\text { with regard to sustained } \\
\text { glucocorticoid-free } \\
\text { remission }^{126,127}\end{array}$ & Tocilizumab \\
\hline $\begin{array}{l}\text { Takayasu } \\
\text { arteritis }\end{array}$ & NA & NA & $\begin{array}{l}\text { Serum concentrations of } \\
\text { IL- } 6 \text { increased in active } \\
\text { disease }^{125}\end{array}$ & $\begin{array}{l}\text { Tocilizumab had some } \\
\text { effect on time to relapse, } \\
\text { but the primary end point } \\
\text { was not met }{ }^{129}\end{array}$ & Tocilizumab \\
\hline CRS & NA & NA & $\begin{array}{l}\text { Serum concentrations of } \\
\text { IL-6 increased }\end{array}$ & $\begin{array}{l}\text { Tocilizumab was used to } \\
\text { successfully treat CRS } \\
\text { occurring in trials of CAR } \\
\text { T cell therapy }{ }^{136,137}\end{array}$ & Tocilizumab \\
\hline
\end{tabular}

CAR, chimeric antigen receptor; CRS, cytokine release syndrome; JIA, juvenile idiopathic arthritis; NA, not available; PBMC, peripheral blood mononuclear cell; RA, rheumatoid arthritis; sIL-6R, soluble IL-6 receptor. 
vital capacity compared with the placebo group, but improvements in skin thickening (measured by the modified Rodnan skin score) with tocilizumab were not statistically significant ${ }^{120}$. Results of a follow-up phase III double-blind, placebo-controlled trial in 212 patients with progressive SSc again showed a numerical reduction in skin score with tocilizumab at week 48 , but the difference did not reach statistical significance ${ }^{121}$. Regarding the mean change in forced vital capacity from baseline to week 48 , tocilizumab performed better than placebo, suggesting a potentially clinically important effect of tocilizumab on the preservation of lung function ${ }^{121}$.

\section{IL-6 inhibition in vasculitis and PMR}

Takayasu arteritis and GCA are chronic, potentially life-threatening, primary systemic large-vessel vasculitides ${ }^{122,123}$. Takayasu arteritis affects the aorta and its major branches in adolescents and young adults, whereas GCA affects large and medium-sized arteries and usually affects individuals above the age of 50 years.

IL-6 was implicated as an important factor in the pathogenesis of both GCA and Takayasu arteritis in the 1990s. First, the serum level of IL- 6 correlated with disease activity in both diseases ${ }^{124,125}$. Second, tocilizumab improved disease signs and symptoms in patients with refractory GCA or refractory Takayasu arteritis in case series. Subsequently, a single-centre phase II RCT and a phase III multicentre, double-blind RCT investigated whether tocilizumab could sustain remission and enable glucocorticoid tapering ${ }^{126,127}$. In the phase III RCT, sustained glucocorticoid-free remission at 52 weeks was achieved in more patients treated with tocilizumab weekly (56\%) or every other week (53\%) (in combination with a prednisone taper over 26 weeks) than in patients who received placebo plus a prednisone taper over 26 weeks (14\%) or placebo plus a prednisone taper over 52 weeks $(18 \%)^{127}$. Consequently, tocilizumab was approved for the treatment of patients with GCA by the FDA and EMA in 2017, making this the first drug approved for the treatment of GCA other than glucocorticoids. A phase III trial evaluating the efficacy and safety of sarilumab in patients with GCA is ongoing ${ }^{128}$.

In Takayasu arteritis, a double-blind RCT in Japan showed that, compared with placebo, tocilizumab treatment prolonged the time to relapse during glucocorticoid tapering ${ }^{129}$. Although the primary end point of the study was not met, tocilizumab has been approved in Japan for the treatment of Takayasu arteritis that is refractory to existing therapies.

Polymyalgia rheumatica (PMR) is a disease closely related to GCA, with stiffness and muscle pain being the predominant symptoms. Several case reports and a small, prospective, open-label phase II trial of tocilizumab in patients with PMR suggested that this drug might have a steroid-sparing effect $^{130,131}$. Another prospective, open-label study found tocilizumab monotherapy to be effective in new-onset $\mathrm{PMR}^{132}$. Additional trials of IL-6 pathway inhibition in PMR are ongoing, including phase III trials of tocilizumab and sarilumab ${ }^{133,134}$.

\section{IL-6 inhibition in CRS}

Tocilizumab was approved by the FDA (in 2017) and the EMA (in 2018) for the treatment of severe or life-threatening chimeric antigen receptor (CAR) $\mathrm{T}$ cell-induced CRS in adults and children. CAR T cells are ex vivo-modified T cells from patients with cancer that are reprogrammed to lyse tumour cells when bound to a specific cancer cell surface protein. However, $70 \%$ of patients treated with a CD19 CAR T cell therapy develop CRS ${ }^{135}$. CRS leads to headache, fever, chills, severe nausea, vomiting, diarrhoea, musculoskeletal pain, dyspnoea, hypotension and tachycardia and in severe cases can be fatal. The approval of tocilizumab for the treatment of CAR $\mathrm{T}$ cell-induced CRS was based on a retrospective analysis of data showing the efficacy of tocilizumab treatment in patients who developed CRS after CAR T cell therapy in prospective clinical trials ${ }^{136-138}$.

\section{Other potential indications}

Unravelling the therapeutic potential of IL-6 pathway inhibition for indications other than those discussed above is a matter of ongoing basic and clinical research spanning various therapeutic areas ${ }^{4,5}$. Several investigator-initiated studies are either planned or ongoing or have already been published as proof-of-concept studies. A detailed representation of all of these studies is beyond the scope of this article, but briefly, they encompass conditions such as uveitis, thyroid eye disease, neuromyelitis optica, graft-versus-host disease, erosive hand osteoarthritis, various oncological indications, depression, schizophrenia, Schnitzler syndrome, myocardial infarction, familial Mediterranean fever and COVID-19 pneumonia (caused by the novel coronavirus SARS-CoV-2) $)^{5,139,140}$. The potential of IL-6 pathway inhibition in COVID-19 pneumonia is supported by studies in which elevated concentrations of IL- 6 have been reported, together with several laboratory abnormalities suggestive of hyperinflammation, especially in patients admitted to intensive care units ${ }^{141}$. A phase II trial is ongoing in Italy ${ }^{142}$ and, in March 2020, a phase III trial was approved by the $\mathrm{FDA}^{143}$ to assess the effect of tocilizumab for severe COVID-19 pneumonia. It is hoped that findings from some of these studies will expand the application and medical value of IL-6 pathway inhibition to additional diseases in the future.

\section{Safety of IL-6 inhibition}

The safety profile of IL-6R inhibition is derived mainly from clinical trials of tocilizumab and sarilumab, as well as data from real-world registries of more than 1 million patients worldwide who have been treated with tocilizumab, including patients with RA, JIA and GCA ${ }^{26,53,144-167}$.

Consistent with expectations for a biologic DMARD for RA, serious infections, including serious bacterial infections, are among the most common serious adverse events reported in clinical trials, post-marketing surveillance studies, short-term studies and open-label extension studies. The overall rate of serious infections in patients with long-term exposure to IL-6 pathway inhibitors is in line with rates seen in studies with a short duration of exposure ${ }^{58,145,159,161,164-169}$.

Treatment with IL-6 pathway inhibitors has been associated with elevations in serum concentrations of transaminases. These elevations did not seem to result in permanent or clinically evident hepatic injury in clinical trials. An increased frequency and magnitude of transaminase elevations was observed when potentially hepatotoxic drugs (for example, methotrexate) were used in combination with IL-6 pathway inhibitors $^{164-167}$.

Pancreatitis is among the adverse reactions identified during post-approval use of tocilizumab and sarilumab ${ }^{164,166}$. Gastrointestinal perforations have also been associated with use of these drugs; most such events occurred in patients with pre-existing risk factors (such as pre-existing diverticulitis or use of oral glucocorticoids); thus, IL-6 pathway inhibitors should be used with caution in patients with a history of gastrointestinal perforation, intestinal ulcers or diverticulitis. The overall rate of gastrointestinal perforations in populations with long-term exposure was in line with rates seen in short-duration studies ${ }^{26,164-167}$.

Monitoring of lipid profiles and treatment of hyperlipidaemia according 
to clinical practice guidelines is recommended during treatment with IL-6 inhibitors, as IL-6 pathway inhibition is associated with increased serum lipid concentrations (LDL and triglycerides) ${ }^{154,156}$. Interestingly, IL-6 inhibition modifies HDL lipoproteins towards an anti-inflammatory composition; thus, the atherogenic index is unchanged ${ }^{170-172}$. In the ENTRACTE study, a head-to-head RCT comparing the cardiovascular safety of tocilizumab and the TNF inhibitor etanercept in RA, the rate of major adverse cardiovascular events was similar with both treatments (HR 1.05, 95\% CI 0.77-1.43) $)^{173}$.

One safety concern of biologic therapies is the development of anti-drug antibodies, which can lead to loss of efficacy and/or immune-mediated adverse reactions ${ }^{174}$. A study evaluating the immunogenicity of tocilizumab in patients with RA found that the incidence of antibodies to tocilizumab was low, regardless of the route of administration of tocilizumab or whether it was used as monotherapy or in combination with csDMARDs; moreover, antibodies to tocilizumab were mostly transient, and their development did not correlate with pharmacokinetics, safety events or loss of efficacy ${ }^{174}$.

For sirukumab, the FDA declined to approve the drug for use in RA owing to concerns regarding an imbalance in all-cause mortality between the sirukumab and placebo groups in phase III studies, although whether this imbalance was a true safety signal or a result of study design is unclear $^{175}$. Additional studies are needed to further define the safety profile of sirukumab.

In general, monitoring for adverse events should always follow local labels, which are continuously updated with the latest safety information $^{164-167}$.

\section{Conclusions}

Substantial advances have been made in translating the biology of IL- 6 to the treatment of patients with autoimmune diseases. Accumulating safety data on IL-6 pathway inhibitors have provided clinicians with the necessary knowledge for assessing the risk of using them. IL-6 pathway inhibitors have shown benefit in patients with RA, JIA, AOSD, GCA, Castleman disease and CRS and might also be beneficial in patients with other autoimmune diseases and even beyond. However, the limitations of preclinical studies for predicting clinical success in patients is a major barrier and necessitates early human proof-of-concept studies. Case reports or series have proved useful in some conditions such as GCA, Takayasu arteritis, AOSD and CRS. In the future, trials to assess the efficacy and safety of a specific treatment within a biomarker-positive subgroup in heterogeneous patient populations (for example, a basket trial) to confirm and generate hypotheses might be an option. However, a reliable biomarker for predicting treatment response in many rheumatic diseases has not been identified.

Several questions relating to IL-6 biology remain unanswered. For example, why does IL-6 over-production occur and why does IL-6 signal inhibition lead to clinically meaningful benefits for patients with some diseases associated with IL-6 over-production (such as RA), but not all (such as AS)? Answering these questions would help to further progress our understanding of how various autoimmune diseases are regulated in the context of IL-6 pathway biology and would help in developing additional, personalized treatment options for individual patients or patient subgroups. It seems that the journey of realizing the therapeutic potential of IL- 6 pathway inhibition is far from over.

Ernest H. Choy $\left(\mathbb{D}^{\prime \otimes} \otimes\right.$, Fabrizio De Benedetti ${ }^{2}$ Tsutomu Takeuchi (iD ${ }^{3}$, Misato Hashizume ${ }^{4}$, Markus R. John ${ }^{5}$ and Tadamitsu Kishimoto ${ }^{6}$ 'Division of Infection and Immunity, CREATE Centre, Cardiff University, Cardiff, UK

${ }^{2}$ Division of Rheumatology and Laboratory of ImmunoRheumatology, Ospedale Pediatrico Bambino Gesù, Rome, Italy.

${ }^{3}$ Division of Rheumatology, Department of Internal Medicine, Keio University School of Medicine, Tokyo, Japan.

${ }^{4}$ Chugai Pharmaceutical Co., Ltd, Tokyo, Japan. ${ }^{5}$ F. Hoffmann-La Roche AG, Basel, Switzerland.

${ }^{6}$ Laboratory of Immune Regulation, World Premier International Immunology Frontier Research Center, Osaka University, Osaka, Japan.

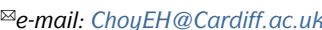

https://doi.org/10.1038/s41584-020-0419-z

Published online 23 April 2020

1. Kishimoto, T. \& Ishizaka, K. Regulation of antibody response in vitro. VII. Enhancing soluble factors for IgG and IgE antibody response. J. Immunol. 111. 1194-1205 (1973).

2. Hirano, T. et al. Complementary DNA for a novel human interleukin (BSF-2) that induces B lymphocytes to produce immunoglobulin. Nature $324,73-76$ (1986).

3. Hashizume, M. et al. Tocilizumab, a humanized anti-IL-6R antibody, as an emerging therapeutic option for rheumatoid arthritis: molecular and cellular mechanistic insights. Int. Rev. Immunol. 34, 265-279 (2015).

4. Garbers, C., Heink, S., Korn, T \& Rose-John, S Interleukin-6: designing specific therapeutics for a complex cytokine. Nat. Rev. Drug Discov. 17 , 395-412 (2018)

5. Kang, S., Tanaka, T., Narazaki, M. \& Kishimoto, T. Targeting interleukin-6 signaling in clinic. Immunity 50, 1007-1023 (2019)

6. Hibi, M. et al. Molecular cloning and expression of an IL-6 signal transducer, gp 130. Cell 63, 1149-1157 (1990).
7. Yawata, H. et al. Structure-function analysis of human IL-6 receptor: dissociation of amino acid residues required for IL-6-binding and for IL-6 signal transduction through gp 130. EMBO J.12, 1705-1712 (1993).

8. Waage, A., Kaufmann, C., Espevik, T. \& Husby, G Interleukin-6 in synovial fluid from patients with arthritis. Clin. Immunol. Immunopathol. 50, 394-398 (1989).

9. Meyers, F. J. et al. Bladder cancer. human leukocyte antigen II, interleukin-6, and interleukin- 6 receptor expression determined by the polymerase chain reaction. Cancer 67, 2087-2095 (1991).

10. Riechmann, L., Clark, M., Waldmann, H. \& Winter, G. Reshaping human antibodies for therapy. Nature 332 , 323-327 (1988)

11. Sato, K. et al. Reshaping a human antibody to inhibit the interleukin 6-dependent tumor cell growth. Cancer Res. 53, 851-856 (1993)

12. Mihara, M. et al. Tocilizumab inhibits signal transduction mediated by both mIL-6R and SIL-6R, but not by the receptors of other members of IL- 6 cytokine family. Int. Immunopharmacol. $\mathbf{5}$ 1731-1740 (2005).

13. Kawano, M. et al. Autocrine generation and requirement of BSF-2/IL-6 for human multiple myelomas. Nature 332, 83-85 (1988)

14. Bataille, R. et al. Biologic effects of anti-interleukin- 6 murine monoclonal antibody in advanced multiple myeloma. Blood 86, 685-691 (1995).

15. Lu, Z. Y. et al. Measurement of whole body interleukin-6 (IL-6) production: prediction of the efficacy of anti-IL-6 treatments. Blood 86 3123-3231 (1995).

16. San-Miguel, J. et al. Phase 2 randomized study of bortezomib-melphalan-prednisone with or without siltuximab (anti-IL-6) in multiple myeloma. Blood 123 4136-4142 (2014)

17. Yoshizaki, K. et al. Pathogenic significance of interleukin-6 (IL-6/BSF-2) in Castleman's disease. Blood 74, 1360-1367 (1989).

18. Suematsu, S. et al. IgG1 plasmacytosis in interleukin 6 transgenic mice. Proc. Natl Acad. Sci. USA 86 7547-7551 (1989).

19. Katsume, A. et al. Anti-interleukin 6 (IL-6) receptor antibody suppresses Castleman's disease like symptoms emerged in IL-6 transgenic mice. Cytokine 20, 304-311 (2002).

20. Beck, J. T. et al. Brief report: alleviation of systemic manifestations of Castleman's disease by monoclonal anti-interleukin-6 antibody. N. Engl. J. Med. 330 602-605 (1994).

21. Nishimoto, N. et al. Improvement in Castleman's disease by humanized anti-interleukin- 6 receptor antibody therapy. Blood 95, 56-61 (2000).

22. Nishimoto, $N$. et al. Humanized anti-interleukin- 6 receptor antibody treatment of multicentric Castleman disease. Blood 106, 2627-2632 (2005).

23. van Rhee, F. et al. Siltuximab for multicentric Castleman's disease: a randomised, double-blind, placebo-controlled trial. Lancet Oncol. 15, 966-974 (2014).

24. Mitsuyama, K. et al. Soluble interleukin- 6 receptors in inflammatory bowel disease: relation to circulating interleukin-6. Gut 36, 45-49 (1995).

25. Ito, $\mathrm{H}$. et al. A pilot randomized trial of a human anti-interleukin-6 receptor monoclonal antibody in active Crohn's disease Gastroenterology 126 , 989-996 (2004).

26. Monemi, S. et al. Incidence of gastrointestinal perforations in patients with rheumatoid arthritis treated with tocilizumab from clinical trial, postmarketing and real-world data sources. Rheumatol. Ther. 3, 337-352 (2016).

27. Guerne, P. A., Zuraw, B. L., Vaughan, J. H., Carson, D. A $\&$ Lotz, M. Synovium as a source of interleukin 6 in vitro. Contribution to local and systemic manifestations of arthritis. J. Clin Invest 83 585-592 (1989).

28. Jilka, R. L. et al. Increased osteoclast development after estrogen loss: mediation by interleukin- 6 . Science 257, 88-91 (1992)

29. van de Loo, F. A., Joosten, L. A., van Lent, P. L., Arntz, O. J. \& van den Berg, W. B. Role of interleukin-1, tumor necrosis factor alpha, and interleukin- 6 in cartilage proteoglycan metabolism and destruction. Effect of in situ blocking in murine antigen- and zymosan-induced arthritis. Arthritis Rheum. 38, 164-172 (1995)

30. Poli, V. et al. Interleukin-6 deficient mice are protected from bone loss caused by estrogen depletion. EMBO J. 13, 1189-1196 (1994). 
31. Takagi, N. et al. Blockage of interleukin-6 receptor ameliorates joint disease in murine collagen-induced arthritis. Arthritis Rheum. 41, 2117-2121 (1998).

32. Fujimoto, M. et al. Interleukin- 6 blockade suppresses autoimmune arthritis in mice by the inhibition of inflammatory $\mathrm{T}_{\mathrm{H}} 17$ responses. Arthritis Rheum. $\mathbf{5 8}$ 3710-3719 (2008).

33. Ohshima, S. et al. Interleukin 6 plays a key role in the development of antigen-induced arthritis. Proc. Natl Acad. Sci. USA 95, 8222-8226 (1998)

34. Wendling, D., Racadot, E. \& Wijdenes, J. Treatment of severe rheumatoid arthritis by anti-interleukin 6 monoclonal antibody. J. Rheumatol. 20, 259-262 (1993).

35. Nishimoto, N., Kishimoto, T. \& Yoshizaki, K. Anti-interleukin 6 receptor antibody treatment in rheumatic disease. Ann. Rheum. Dis. 59 (Suppl. 1), i21-i27 (2000)

36. Choy, E. H. et al. Therapeutic benefit of blocking interleukin- 6 activity with an anti-interleukin- 6 receptor monoclonal antibody in rheumatoid arthritis: a randomized, double-blind, placebo-controlled, dose-escalation trial. Arthritis Rheum. 46, 3143-3150 (2002)

37. Nishimoto, N. et al. Treatment of rheumatoid arthritis with humanized anti-interleukin- 6 receptor antibody: a multicenter, double-blind, placebo-controlled trial. Arthritis Rheum. 50, 1761-1769 (2004).

38. Maini, R. N. et al. Double-blind randomized controlled clinical trial of the interleukin-6 receptor antagonist, tocilizumab, in European patients with rheumatoid arthritis who had an incomplete response to methotrexate. Arthritis Rheum. 54, 2817-2829 (2006).

39. Nishimoto, N. et al. Study of active controlled monotherapy used for rheumatoid arthritis, an IL-6 inhibitor (SAMURAI): evidence of clinical and radiographic benefit from an $\mathrm{x}$ ray reader-blinded randomised controlled trial of tocilizumab. Ann Rheum. Dis. 66, 1162-1167 (2007)

40. Jones, G. et al. Comparison of tocilizumab monotherapy versus methotrexate monotherapy in patients with moderate to severe rheumatoid arthritis: the AMBITION study. Ann. Rheum. Dis. 69, 88-96 (2010)

41. Emery, P. et al. IL-6 receptor inhibition with tocilizumab improves treatment outcomes in patients with rheumatoid arthritis refractory to anti-tumour necrosis factor biologicals: results from a 24-week multicentre randomised placebo-controlled trial. Ann. Rheum. Dis. 67, 1516-1523 (2008)

42. Genovese, M. C. et al. Interleukin- 6 receptor inhibition with tocilizumab reduces disease activity in rheumatoid arthritis with inadequate response to disease-modifying antirheumatic drugs: the tocilizumab in combination with traditional disease-modifying antirheumatic drug therapy study. Arthritis Rheum. 58, 2968-2980 (2008).

43. Smolen, J. S. et al. Effect of interleukin- 6 receptor inhibition with tocilizumab in patients with rheumatoid arthritis (OPTION study): a double-blind, placebo-controlled, randomised trial. Lancet 371 , 987-997 (2008)

44. Kremer, J. M. et al. Tocilizumab inhibits structural joint damage in rheumatoid arthritis patients with inadequate responses to methotrexate: results from the double-blind treatment phase of a randomized placebo-controlled trial of tocilizumab safety and prevention of structural joint damage at one year. Arthritis Rheum. 63, 609-621 (2011)

45. Takeuchi, T. et al. Clinical, radiographic and functional effectiveness of tocilizumab for rheumatoid arthritis patients-REACTION 52-week study. Rheumatology 50, 1908-1915 (2011)

46. Gabay, C. et al. Tocilizumab monotherapy versus adalimumab monotherapy for treatment of rheumatoid arthritis (ADACTA): a randomised, double-blind, controlled phase 4 trial. Lancet 381 . 1541-1550 (2013)

47. Dougados, M. et al. Adding tocilizumab or switching to tocilizumab monotherapy in methotrexate inadequate responders: 24-week symptomatic and structural results of a 2-year randomised controlled strategy trial in rheumatoid arthritis (ACT-RAY). Ann. Rheum. Dis. 72, 43-50 (2013).

48. Dougados, M. et al. Clinical, radiographic and immunogenic effects after 1 year of tocilizumab-based treatment strategies in rheumatoid arthritis: the ACT-RAY study. Ann. Rheum. Dis. 73, 803-809 (2014).

49. Kaneko, Y. et al. Comparison of adding tocilizumab to methotrexate with switching to tocilizumab in patients with rheumatoid arthritis with inadequate response to methotrexate: 52-week results from a prospective, randomised, controlled study (SURPRISE study). Ann. Rheum. Dis. 75, 1917-1923 (2016).

50. Teitsma, X. M., Marijnissen, A. K., Bijlsma, J. W., Lafeber, F. P. \& Jacobs, J. W. Tocilizumab as monotherapy or combination therapy for treating active rheumatoid arthritis: a meta-analysis of efficacy and safety reported in randomized controlled trials. Arthritis Res. Ther. 18, 211 (2016).

51. Burmester, G. R. et al. Tocilizumab in early progressive rheumatoid arthritis: FUNCTION, a randomised controlled trial. Ann. Rheum. Dis. 75, 1081-1091 (2016).

52. Strand, V. et al. Impact of tocilizumab monotherapy on patient-reported outcomes in patients with rheumatoid arthritis from two randomised controlled trials. RMD Open 3, e000496 (2017).

53. Jones, G. et al. Five-year efficacy and safety of tocilizumab monotherapy in patients with rheumatoid arthritis who were methotrexate- and biologic-naive or free of methotrexate for 6 months: the AMBITION study. J. Rheumatol. 44, 142-146 (2017).

54. Burmester, G. R. et al. Tocilizumab combination therapy or monotherapy or methotrexate monotherapy in methotrexate-naive patients with early rheumatoid arthritis: 2-year clinical and radiographic results from the randomised, placebocontrolled FUNCTION trial. Ann. Rheum. Dis. 76 1279-1284 (2017).

55. Edwards, C. J., Ostor, A. J. K., Naisbett-Groet, B. \& Kiely, P. Tapering versus steady-state methotrexate in combination with tocilizumab for rheumatoid arthritis: a randomized, double-blind trial. Rheumatology 57 84-91 (2018)

56. Kaneko, Y. et al. Tocilizumab discontinuation after attaining remission in patients with rheumatoid arthritis who were treated with tocilizumab alone or in combination with methotrexate: results from a prospective randomised controlled study (the second year of the SURPRISE study). Ann. Rheum. Dis. 77 1268-1275 (2018).

57. Kremer, J. M. et al. Sustained response following discontinuation of methotrexate in patients with rheumatoid arthritis treated with subcutaneous tocilizumab: results from a randomized, controlled trial. Arthritis Rheumatol. 70, 1200-1208 (2018).

58. Rubbert-Roth, A., Furst, D. E., Nebesky, J. M., Jin, A. $\S$ Berber, E. A review of recent advances using tocilizumab in the treatment of rheumatic diseases. Rheumatol. Ther. 5, 21-42 (2018).

59. Teitsma, X. M. et al. Inadequate response to treat-to-target methotrexate therapy in patients with new-onset rheumatoid arthritis: development and validation of clinical predictors. Ann. Rheum. Dis. 77, 1261-1267 (2018).

60. Smolen, J. S. et al. EULAR recommendations for the management of rheumatoid arthritis with synthetic and biological disease-modifying antirheumatic drugs: 2019 update. Ann. Rheum. Dis. https://doi.org/ 10.1136/annrheumdis-2019-216655 (2020).

61. Dutch Association for Rheumatology. NVR Standpunt Tocilizumab Verklaring Commissie Kwaliteit. https:// www.nvr.nl/wp-content/uploads/2018/09/NVRStandpunt-Tocilizumab-verklaring-commissie-kwaliteitnov-2009.pdf (2009)

62. Finzel, S. et al. Comparison of the effects of tocilizumab monotherapy and adalimumab in combination with methotrexate on bone erosion repair in rheumatoid arthritis. Ann. Rheum. Dis. 78 1186-1191 (2019).

63. Fonseca, J. E. et al. Portuguese guidelines for the use of biological agents in rheumatoid arthritis-October 2011 update. Acta Reumatol. Port. 36, 385-358 (2011).

64. Swedish Rheumatological Association. Guidelines for the pharmaceutical management of rheumatoid arthritis. http://svenskreumatologi.se/wp-content/ uploads/2016/08/guidelines_for_the_pharmaceutical_ management_of_rheumatoid_arthritis.pdf (2011).

65. Gaujoux-Viala, C. et al. Recommendations of the French Society for Rheumatology for managing rheumatoid arthritis. Joint Bone Spine 81, 287-297 (2014).

66. Albrecht, K. et al. German guidelines for the sequential medical treatment of rheumatoid arthritis with traditional and biologic disease-modifying antirheumatic drugs. Rheumatol. Int. 34, 1-9 (2014)

67. National Institute for Health and Care Excellence. Adalimumab, etanercept, infliximab, certolizumab pegol, golimumab, tocilizumab and abatacept for rheumatoid arthritis not previously treated with
DMARDs or after conventional DMARDs only have failed. https://www nice.org uk/guidance/TA375 (NICE, 2016).

68. Smolen, J. S. et al. EULAR recommendations for the management of rheumatoid arthritis with synthetic and biological disease-modifying antirheumatic drugs: 2016 update Ann. Rheum. Dis. 76, 960-977 (2017).

69. Garcia-Vicuna, R. et al. Recommendations by the Spanish Society of Rheumatology for the managemen of patients diagnosed with rheumatoid arthritis who cannot be treated with methotrexate. Reumatol. Clin. 13, 127-138 (2017)

70. Duarte, C. et al. Portuguese recommendations for the use of biological therapies in patients with rheumatoid arthritis-2016 update. Acta Reumatol. Port. 42. 112-126 (2017).

71. Moreland, L. W. \& Curtis, J. R. Systemic nonarticular manifestations of rheumatoid arthritis: focus on inflammatory mechanisms. Semin. Arthritis Rheum 39, 132-143 (2009)

72. Davis, M. C. et al. Chronic stress and regulation of cellular markers of inflammation in rheumatoid arthritis: implications for fatigue. Brain Behav. Immun. 22, 24-32 (2008)

73. Boyapati, A. et al. Sarilumab plus methotrexate suppresses circulating biomarkers of bone resorption and synovial damage in patients with rheumatoid arthritis and inadequate response to methotrexate: a biomarker study of MOBILITY. Arthritis Res. Ther 18, 225 (2016).

74. Fleischmann, R. et al. Sarilumab and nonbiologic disease-modifying antirheumatic drugs in patients with active rheumatoid arthritis and inadequate response or intolerance to tumor necrosis factor inhibitors. Arthritis Rheumatol. 69, 277-290 (2017).

75. Burmester, G. R. et al. Efficacy and safety of sarilumab monotherapy versus adalimumab monotherapy for the treatment of patients with active rheumatoid arthritis (MONARCH): a randomised, double-blind parallel-group phase III trial. Ann. Rheum. Dis. 76, 840-847 (2017).

76. Takeuchi, T. et al. Sirukumab for rheumatoid arthritis: the phase III SIRROUND-D study. Ann. Rheum. Dis. 76, 2001-2008 (2017)

77. Aletaha, D. et al. Efficacy and safety of sirukumab in patients with active rheumatoid arthritis refractory to anti-TNF therapy (SIRROUND-T): a randomised, double-blind, placebo-controlled, parallel-group, multinational, phase 3 study. Lancet 389 , 1206-1217 (2017).

78. Taylor, P. C. et al. Efficacy and safety of monotherapy with sirukumab compared with adalimumab monotherapy in biologic-naive patients with active rheumatoid arthritis (SIRROUND-H): a randomised, double-blind, parallel-group, multinational, 52-week, phase 3 study. Ann. Rheum. Dis. 77, 658-666 (2018).

79. Genovese, M. C. et al. Efficacy and safety of olokizumab in patients with rheumatoid arthritis with an inadequate response to TNF inhibitor therapy: outcomes of a randomised phase llb study. Ann. Rheum. Dis. 73, 1607-1615 (2014).

80. Ravelli, A. \& Martini, A. Juvenile idiopathic arthritis. Lancet 369, 767-778 (2007).

81. De Benedetti, F. et al. Serum soluble interleukin 6 (IL-6) receptor and IL-6/soluble IL-6 receptor complex in systemic juvenile rheumatoid arthritis. J. Clin. Invest. 93, 2114-2119 (1994).

82. Cazzola, M. et al. Defective iron supply for erythropoiesis and adequate endogenous erythropoietin production in the anemia associated with systemic-onset juvenile chronic arthritis. Blood 87, 4824-4830 (1996).

83. De Benedetti, F. et al. Interleukin 6 causes growth impairment in transgenic mice through a decrease in insulin-like growth factor-I. A model for stunted growth in children with chronic inflammation. J. Clin. Invest. 99, 643-650 (1997).

84. De Benedetti, F. et al. Impaired skeletal development in interleukin-6-transgenic mice: a model for the impact of chronic inflammation on the growing skeletal system. Arthritis Rheum. 54, 3551-3563 (2006).

85. Hinze, C. Gohar, F. \& Foell, D. Management of juvenile idiopathic arthritis: hitting the target. Nat. Rev. Rheumatol. 11, 290-300 (2015).

86. Woo, P. et al. Open label phase II trial of single, ascending doses of MRA in Caucasian children with severe systemic juvenile idiopathic arthritis: proof of principle of the efficacy of IL- 6 receptor blockade in this type of arthritis and demonstration of prolonged clinical improvement. Arthritis Res. Ther. 7.

R1281-R1288 (2005). 
87. Yokota, S. et al. Therapeutic efficacy of humanized recombinant anti-interleukin- 6 receptor antibody in children with systemic-onset juvenile idiopathic arthritis. Arthritis Rheum. 52, 818-825 (2005).

88. Yokota, S. et al. Efficacy and safety of tocilizumab in patients with systemic-onset juvenile idiopathic arthritis: a randomised double-blind, placebo-controlled, withdrawal phase III trial. Lancet 371, 998-1006 (2008)

89. De Benedetti, F. et al. Randomized trial of tocilizumab in systemic juvenile idiopathic arthritis. N. Engl. J. Med. 367, 2385-2395 (2012)

90. Yokota, S. et al. Long-term treatment of systemic juvenile idiopathic arthritis with tocilizumab: results of an open-label extension study in Japan. Ann. Rheum. Dis. 72, 627-628 (2013)

91. Yokota, S. et al. Longterm safety and effectiveness of the anti-interleukin 6 receptor monoclonal antibody tocilizumab in patients with systemic juvenile idiopathic arthritis in Japan. J. Rheumatol. 41, 759-767 (2014)

92. De Benedetti, $F$ et al Catch-up growth during tocilizumab therapy for systemic juvenile idiopathic arthritis: results from a phase III trial. Arthritis Rheumatol. 67, 840-848 (2015).

93. Yokota, S. et al. Tocilizumab in systemic juvenile idiopathic arthritis in a real-world clinical setting: results from 1 year of postmarketing surveillance follow-up of 417 patients in Japan. Ann. Rheum. Dis. 75, 1654-1660 (2016)

94. Kaneko, Y. et al. Tocilizumab in patients with adult-onset Still's disease refractory to glucocorticoid treatment: a randomised, double-blind, placebo-controlled phase III trial. Ann. Rheum. Dis. 77, 1720-1729 (2018)

95. Imagawa, T. et al. Safety and efficacy of tocilizumab, an anti-IL-6-receptor monoclonal antibody, in patients with polyarticular-course juvenile idiopathic arthritis. Mod. Rheumatol. 22, 109-115 (2012).

96. Brunner, H. I. et al. Efficacy and safety of tocilizumab in patients with polyarticular-course juvenile idiopathic arthritis: results from a phase 3 , randomised, double-blind withdrawal trial. Ann. Rheum. Dis. 74, 1110-1117 (2015)

97. Bharucha, K. N. et al. Growth during tocilizumab therapy for polyarticular-course juvenile idiopathic arthritis: 2-year data from a phase III clinical trial. J. Rheumatol. 45, 1173-1179 (2018)

98. US National Library of Medicine. ClinicalTrials.gov https://clinicaltrials.gov/ct2/show/NCT02776735 (2020).

99. US National Library of Medicine. ClinicalTrials.gov https://clinicaltrials.gov/ct2/show/NCT02991469 (2020).

100. Ambarus, C., Yeremenko, N., Tak, P. P. \& Baeten, D. Pathogenesis of spondyloarthritis: autoimmune or autoinflammatory? Curr. Opin. Rheumatol. 24, 351-358 (2012)

101. Ranganathan, V., Gracey, E., Brown, M. A., Inman, R. D \& Haroon, N. Pathogenesis of ankylosing spondylitis - recent advances and future directions. Nat. Rev. Rheumatol. 13, 359-367 (2017).

102. Gratacos, J. et al. Serum cytokines (IL-6, TNF-alpha, IL-1 beta and IFN-gamma) in ankylosing spondylitis: a close correlation between serum IL- 6 and disease activity and severity. Br. J. Rheumatol. 33, 927-931 (1994).

103. Sieper, J., Porter-Brown, B., Thompson, L., Harari, O. $£$ Dougados, M. Assessment of short-term symptomatic efficacy of tocilizumab in ankylosing spondylitis: results of randomised, placebo-controlled trials. Ann. Rheum. Dis. 73, 95-100 (2014).

104. Sieper, J. et al. Sarilumab for the treatment of ankylosing spondylitis: results of a phase II randomised, double-blind, placebo-controlled study (ALIGN). Ann. Rheum. Dis. 74, 1051-1057 (2015).

105. Scher, J. U., Ogdie, A., Merola, J. F. \& Ritchlin, C. Preventing psoriatic arthritis: focusing on patients with psoriasis at increased risk of transition. Nat. Rev. Rheumatol. 15, 153-166 (2019).

106. Partsch, G. et al. Highly increased levels of tumor necrosis factor-alpha and other proinflammatory cytokines in psoriatic arthritis synovial fluid. J. Rheumatol. 24, 518-523 (1997)

107. van Kuijk, A. W., Reinders-Blankert, P., Smeets, T. J., Dijkmans, B. A. \& Tak, P. P. Detailed analysis of the cell infiltrate and the expression of mediators of synovial inflammation and joint destruction in the synovium of patients with psoriatic arthritis: implications for treatment. Ann. Rheum. Dis. 65, 1551-1557 (2006).

108. Mease, P. J. et al. The efficacy and safety of clazakizumab, an anti-interleukin-6 monoclonal antibody, in a phase Ilb study of adults with active psoriatic arthritis. Arthritis Rheumatol. 68 2163-2173 (2016)

109. Mihara, M. \& Ohsugi, Y. Possible role of IL- 6 in pathogenesis of immune complex-mediated glomerulonephritis in NZB/W F1 mice: induction of IgG class anti-DNA autoantibody production. Int. Arch. Allergy. Appl. Immunol. 93, 89-92 (1990).

110. Hirohata, S. \& Miyamoto, T. Elevated levels of interleukin- 6 in cerebrospinal fluid from patients with systemic lupus erythematosus and central nervous system involvement. Arthritis Rheum. 33, 644-649 (1990).

111. Gordon, C. et al. Urinary IL-6: a marker for mesangial proliferative glomerulonephritis? Clin. Exp. Immunol. 86, 145-149 (1991)

112. Illei, G. G. et al. Tocilizumab in systemic lupus erythematosus: data on safety, preliminary efficacy, and impact on circulating plasma cells from an open-label phase I dosage-escalation study. Arthritis Rheum. 62, 542-552 (2010).

113. Shirota, Y. et al. Impact of anti-interleukin- 6 receptor blockade on circulating $T$ and $B$ cell subsets in patients with systemic lupus erythematosus. Ann. Rheum. Dis. 72, 118-128 (2013)

114. Rovin, B. H. et al. A multicenter, randomized, double-blind, placebo-controlled study to evaluate the efficacy and safety of treatment with sirukumab (CNTO 136) in patients with active lupus nephritis. Arthritis Rheumatol. 68, 2174-2183 (2016)

115. Wallace, D. J. et al. Efficacy and safety of an interleukin 6 monoclonal antibody for the treatment of systemic lupus erythematosus: a phase II dose-ranging randomised controlled trial. Ann. Rheum. Dis. 76 534-542 (2017).

116. Kitaba, S. et al. Blockade of interleukin- 6 receptor alleviates disease in mouse model of scleroderma. Am. J. Pathol. 180, 165-176 (2012).

117. Kadono, T., Kikuchi, K., Ihn, H., Takehara, K. \& Tamaki, K. Increased production of interleukin 6 and interleukin 8 in scleroderma fibroblasts. J. Rheumatol. 25, 296-301 (1998).

118. De Lauretis, A. et al. Serum interleukin 6 is predictive of early functional decline and mortality in interstitial lung disease associated with systemic sclerosis. J. Rheumatol. 40, 435-446 (2013).

119. Shima, Y et al. The skin of patients with systemic sclerosis softened during the treatment with anti-IL-6 receptor antibody tocilizumab. Rheumatology 49 2408-2412 (2010)

120. Khanna, D. et al. Safety and efficacy of subcutaneous tocilizumab in adults with systemic sclerosis (faSScinate): a phase 2, randomised, controlled trial. Lancet 387, 2630-2640 (2016).

121. Khanna, D. et al. Efficacy and safety of tocilizumab for the treatment of systemic sclerosis: results from a phase 3 randomized controlled trial. Arthritis Rheumatol. 70 (Suppl. 10), 898 (2018).

122. Dejaco, C. et al. Giant cell arteritis and polymyalgia rheumatica: current challenges and opportunities. Nat. Rev. Rheumatol. 13, 578-592 (2017).

123. Kim, E. S. H. \& Beckman, J. Takayasu arteritis: challenges in diagnosis and management. Heart 104 558-565 (2018)

124. Dasgupta, B. \& Panayi, G. S. Interleukin-6 in serum of patients with polymyalgia rheumatica and giant cell arteritis. Br. J. Rheumatol. 29, 456-458 (1990).

125. Noris, M., Daina, E., Gamba, S., Bonazzola, S. \& Remuzzi, G. Interleukin- 6 and RANTES in Takayasu arteritis: a guide for therapeutic decisions? Circulation 100, 55-60 (1999).

126. Villiger, P. M. et al. Tocilizumab for induction and maintenance of remission in giant cell arteritis: a phase 2, randomised, double-blind, placebo-controlled trial. Lancet 387, 1921-1927 (2016).

127. Stone, J. H. et al. Trial of tocilizumab in giant-cell arteritis. N. Engl. J. Med. 377, 317-328 (2017)

128. US National Library of Medicine. ClinicalTrials gov https://clinicaltrials.gov/ct2/show/NCT03600805 (2020).

129. Nakaoka, Y. et al. Efficacy and safety of tocilizumab in patients with refractory Takayasu arteritis: results from a randomised, double-blind, placebo-controlled, phase 3 trial in Japan (the TAKT study). Ann. Rheum. Dis. 77, 348-354 (2018)

130. Macchioni, P. et al. Tocilizumab for polymyalgia rheumatica: report of two cases and review of the literature. Semin. Arthritis Rheum. 43, 113-118 (2013).

131. Lally, L., Forbess, L., Hatzis, C. \& Spiera, R. Brief report: a prospective open-label phase lla trial of tocilizumab in the treatment of polymyalgia rheumatica. Arthritis Rheumatol. 68, 2550-2554 (2016).
132. Devauchelle-Pensec, V. et al. Efficacy of first-line tocilizumab therapy in early polymyalgia rheumatica: a prospective longitudinal study. Ann. Rheum. Dis. $\mathbf{7 5}$ 1506-1510 (2016).

133. US National Library of Medicine. ClinicalTrials.gov https://clinicaltrials.gov/ct2/show/NCT03263715 (2020)

134. US National Library of Medicine. ClinicalTrials.go https://clinicaltrials.gov/ct2/show/NCT03600818 (2020).

135. Hay, K. A. Cytokine release syndrome and neurotoxicity after $\mathrm{CD} 19$ chimeric antigen receptormodified (CAR-) T cell therapy. Br. J. Haematol. 183 364-374 (2018)

136. Grupp, S. A. et al. Chimeric antigen receptor-modified T cells for acute lymphoid leukemia. $N$. Engl. J. Med. 368, 1509-1518 (2013)

137. Neelapu, S. S. et al. Axicabtagene ciloleucel CAR T-cell therapy in refractory large B-cell lymphoma. N. Engl. J. Med. 377, 2531-2544 (2017).

138. Le, R. O. et al. FDA approval summary: tocilizumab for treatment of chimeric antigen receptor $\mathrm{T}$ cell-induced severe or life-threatening cytokine release syndrome. Oncologist 23, 943-947 (2018).

139. Mehta, P. et al. COVID-19: consider cytokine storm syndromes and immunosuppression. Lancet 395 , 1033-1034 (2020).

140. Chinese Clinical Trial Registry. Chictr.org.cn http:/ www. chictr.org. cn/showprojen. aspx? proj=49409 (2020).

141. Huang, C. et al. Clinical features of patients infected with 2019 novel coronavirus in Wuhan, China. Lancet 395, 497-506 (2020)

142. US National Library of Medicine. ClinicalTrials.go https://clinicaltrials.gov/ct2/show/NCT04317092 (2020).

143. US National Library of Medicine. ClinicalTrials.gov https://clinicaltrials.gov/ct2/show/NCT04320615 (2020).

144. Koike, T. et al. Postmarketing surveillance of tocilizumab for rheumatoid arthritis in Japan: interim analysis of 3881 patients. Ann. Rheum. Dis. 70, 2148-2151 (2011)

145. Genovese, M. C. et al. Longterm safety and efficacy of tocilizumab in patients with rheumatoid arthritis: a cumulative analysis of up to 4.6 years of exposure. J. Rheumatol. 40, 768-780 (2013).

146. Koike, T. et al. Effectiveness and safety of tocilizumab: postmarketing surveillance of 7901 patients with rheumatoid arthritis in Japan. J. Rheumatol. 41, 15-23 (2014)

147. Yamamoto, K. et al. Longterm safety of tocilizumab: results from 3 years of followup postmarketing surveillance of 5573 patients with rheumatoid arthritis in Japan. J. Rheumatol. 42, 1368-1375 (2015).

148. Burmester, G. R. et al. Efficacy and safety of subcutaneous tocilizumab versus intravenous tocilizumab in combination with traditional DMARDs in patients with RA at week 97 (SUMMACTA) Ann. Rheum. Dis. 75, 68-74 (2016).

149. Kremer, J. M. et al. Clinical efficacy and safety maintained up to 5 years in patients with rheumatoid arthritis treated with tocilizumab in a randomised trial. Clin. Exp. Rheumatol. 34, 625-633 (2016)

150. Flaig, T. et al. Tocilizumab-induced pancreatitis: case report and review of data from the FDA adverse event reporting system. J. Clin. Pharm. Ther 41, 718-721 (2016).

151. Hoeltzenbein, M. et al. Tocilizumab use in pregnancy: analysis of a global safety database including data from clinical trials and post-marketing data. Semin. Arthritis Rheum. 46, 238-245 (2016).

152. Kivitz, A. et al. Long-term safety and efficacy of subcutaneously administered tocilizumab for adult rheumatoid arthritis: a multicenter phase $3 \mathrm{~b}$ long-term extension study. Rheumatol. Ther. 3 291-304 (2016)

153. Genovese, M. C. et al. Transaminase levels and hepatic events during tocilizumab treatment: pooled analysis of long-term clinical trial safety data in rheumatoid arthritis. Arthritis Rheumatol. 69, 1751-1761 (2017).

154. Kim, S. C. et al. Cardiovascular safety of tocilizumab versus tumor necrosis factor inhibitors in patients with rheumatoid arthritis: a multi-database cohort study. Arthritis Rheumatol. 69, 1154-1164 (2017).

155. Papalopoulos, I. et al. Liver safety of non-tumour necrosis factor inhibitors in rheumatic patients with past hepatitis B virus infection: an observational, controlled, long-term study. Clin. Exp. Rheumatol. 36 02-109 (2018) 
156. Kim, S. C. et al. No difference in cardiovascular risk of tocilizumab versus abatacept for rheumatoid arthritis: a multi-database cohort study. Semin. Arthritis Rheum. 48, 399-405 (2018).

157. Rutherford, A. I., Subesinghe, S., Hyrich, K. L. $\&$ Galloway, J. B. Serious infection across biologic-treated patients with rheumatoid arthritis: results from the British Society for Rheumatology Biologics Register for Rheumatoid Arthritis. Ann. Rheum. Dis. 77, 905-910 (2018).

158. Gron, K. L. et al. Risk of serious infections in patients with rheumatoid arthritis treated in routine care with abatacept, rituximab and tocilizumab in Denmark and Sweden. Ann. Rheum. Dis. 78, 320-327 (2019).

159. Curtis, J. R. et al. Tocilizumab in rheumatoid arthritis: a case study of safety evaluations of a large postmarketing data set from multiple data sources. Semin. Arthritis Rheum. 44, 381-388 (2015).

160. Sakai, R. et al. Head-to-head comparison of the safety of tocilizumab and tumor necrosis factor inhibitors in rheumatoid arthritis patients (RA) in clinical practice: results from the registry of Japanese RA patients on biologics for long-term safety (REAL) registry. Arthritis Res. Ther. 17, 74 (2015)

161. Morel, J. et al. Risk factors of serious infections in patients with rheumatoid arthritis treated with tocilizumab in the French Registry REGATE. Rheumatology 56, 1746-1754 (2017).

162. Choy, E. et al. Evaluation of the efficacy and safety of sarilumab combination therapy in patients with rheumatoid arthritis with inadequate response to conventional disease-modifying antirheumatic drugs or tumour necrosis factor alpha inhibitors: systematic literature review and network meta-analyses. $R M D$ Open 5, e000798 (2019).

163. Emery, P. et al. Safety and tolerability of subcutaneous sarilumab and intravenous tocilizumab in patients with rheumatoid arthritis. Rheumatology $\mathbf{5 8}$ 849-858 (2018).

164. Genentech. Tocilizumab package insert in the USA Genentech https://www. gene.com/download/pd/ actemra prescribing.pdf (2019).

165. European Medicines Agency. Tocilizumab summary of product characteristics in EU. EMA http://ec.europa. eu/health/documents/community-register/2018/ 20181029142753/anx 142753 en.pdf (2018).

166. Sanofi. Sarilumab package insert in the USA Sanofi http://products.sanofi.us/kevzara/kevzara.pdf (2018).

167. European Medicines Agency. Sarilumab summary of product characteristics in EU. EMA https://www.ema. europa.eu/en/documents/product-information/kevzaraepar-product-information_en.pdf (2017).

168. Pardeo, M. et al. Neutropenia during tocilizumab treatment is not associated with infection risk in systemic or polyarticular-course juvenile idiopathic arthritis. J. Rheumatol 46, 1117-1126 (2019).

169. Nishimoto, N. et al. Long-term safety and efficacy of tocilizumab, an anti-IL- 6 receptor monoclonal antibody, in monotherapy, in patients with rheumatoid arthritis (the STREAM study): evidence of safety and efficacy in a 5-year extension study. Ann. Rheum. Dis. 68, 1580-1584 (2009).

170. McInnes, I. B. et al. Effect of interleukin- 6 receptor blockade on surrogates of vascular risk in rheumatoid arthritis: MEASURE, a randomised, placebo-controlled study. Ann. Rheum. Dis. 74, 694-702 (2015).

171. Gabay, C. et al. Comparison of lipid and lipid-associated cardiovascular risk marker changes after treatment with tocilizumab or adalimumab in patients with rheumatoid arthritis. Ann. Rheum. Dis. 75, 1806-1812 (2016)

172. Fioravanti, A. et al. Tocilizumab modulates serum levels of adiponectin and chemerin in patients with rheumatoid arthritis: potential cardiovascular protective role of IL-6 inhibition Clin. Exp. Rheumatol. 37, 293-300 (2019)

173. Scott, L. J. Tocilizumab: a review in rheumatoid arthritis. Drugs 77, 1865-1879 (2017).

174. Burmester, G. R. et al. Low immunogenicity of tocilizumab in patients with rheumatoid arthritis. Ann. Rheum. Dis. 76, 1078-1085 (2017).

175. FDA. FDA summary minutes of the Arthritis Advisory Committee Meeting https://www.fda.gov/media/ 107409/download (FDA, 2017).

176. Tsunenari, T. et al. New xenograft model of multiple myeloma and efficacy of a humanized antibody agains human interleukin-6 receptor. Blood 90, 2437-2444 (1997).

177. Bataille, R., Jourdan, M., Zhang, X. G. \& Klein, B. Serum levels of interleukin 6 , a potent myeloma cell growth factor, as a reflect of disease severity in plasma cell dyscrasias. J. Clin. Invest. 84, 2008-2011 (1989).

178. Atreya, R. et al. Blockade of interleukin 6 trans signaling suppresses T-cell resistance against apoptosis in chronic intestinal inflammation: evidence in Crohn disease and experimental colitis in vivo. Nat. Med. 6, 583-588 (2000).

179. Hosokawa, T. et al. Interleukin- 6 and soluble interleukin- 6 receptor in the colonic mucosa of inflammatory bowel disease. J. Gastroenterol. Hepatol. 14, 987-996 (1999).

180. Pignatti, P. et al. Abnormal regulation of interleukin 6 in systemic juvenile idiopathic arthritis. J. Rheumatol. 28, 1670-1676 (2001)

181. De Benedetti, F. et al. Correlation of serum interleukin-6 levels with joint involvement and thrombocytosis in systemic juvenile rheumatoid arthritis. Arthritis Rheum. 34, 1158-1163 (1991).
182. Opoka-Winiarska, V. et al. Long-term, interventional, open-label extension study evaluating the safety of tocilizumab treatment in patients with polyarticularcourse juvenile idiopathic arthritis from Poland and Russia who completed the global, international CHERISH trial. Clin. Rheumatol. 37, 1807-1816 (2018).

183. Hoshino, T. et al. Elevated serum interleukin 6 interferon-gamma, and tumor necrosis factor-alpha levels in patients with adult Still's disease.

J. Rheumatol. 25, 396-398 (1998).

184. Tanaka, Y. et al. Production of B cell-stimulating factors by $B$ cells in patients with systemic lupus erythematosus. J. Immunol. 141, 3043-309 (1988).

185. Gurram, M., Pahwa, S. \& Frieri, M. Augmented interleukin- 6 secretion in collagen-stimulated peripheral blood mononuclear cells from patients with systemic sclerosis. Ann. Allergy 73, 493-496 (1994).

\section{Acknowledgements}

The authors acknowledge the support of B. Sudbeck in compiling clinical trial information.

\section{Competing interests}

E.H.C. has received research grants from Bio-Cancer, Biogen, Novartis, Pfizer, Roche, Sanofi and UCB; consultancy fees from AbbVie, Amgen, Biogen, Chugai Pharma, Eli Lilly, Janssen, Novartis, Pfizer, Regeneron, Roche, R-Pharm and Sanofi; speaker's fees from Amgen, Bristol-Myers Squibb, Chugai Pharma, Eli Lilly, Janssen, Novartis, Pfizer, Regeneron, Roche, Sanofi and UCB. F.D.B. has received research grants from AbbVie, Novartis, Pfizer, Roche, Sanofi, Novimmune and SOBI. T.T. has received research grants from AbbVie, Asahi Kasei Pharma, Astellas Pharma, AYUMI Pharmaceutical, Chugai Pharmaceutical, Daiichi Sankyo, Eisai, Mitsubishi Tanabe Pharma, Nippon Kayaku, Novartis Pharma K.K., Pfizer Japan, Takeda Pharmaceutical; and personal fees from AbbVie G.K., Astellas Pharma, AstraZeneca K.K., Bristol-Myers K.K., Chugai Pharmaceutical, Daiichi Sankyo, Eisai, Eli Lilly Japan K.K., GlaxoSmithKline K.K., Janssen Pharmaceutical K.K., Mitsubishi Tanabe Pharma, Nippon Kayaku, Novartis Pharma K.K., Pfizer Japan, Sanofi K.K., Teijin Pharma, Taiho Pharmaceutical, Taisho Pharmaceutical, Takeda Pharmaceutical, UCB Japan. M.H. is an employee of Chugai Pharmaceutical. M.R.J. is employed by Roche and owns shares in Roche. T.K. has a patent for tocilizumab. Work by T.K.'s group is supported in part by the Kishimoto Foundation.

\section{Publisher's note}

Springer Nature remains neutral with regard to jurisdictional claims in published maps and institutional affiliations.

(c) Springer Nature Limited 2020 